\title{
STUDI PENAMBAHAN STRUKTUR BETON BERTULANG MENJADI KOMPOSIT DENGAN BAJA BERGELOMBANG PADA OVERPASS PUCUNG LOR KROYA
}

\author{
Raden Aufa Dhia Anggara ${ }^{1, *}$, Ashar Saputra ${ }^{2}$ \\ ${ }^{1, *}$ Departemen Teknik Sipil dan Lingkungan, Universitas Gadjah Mada, Yogyakarta \\ Email: radenaufa00@mail.ugm.ac.id \\ ${ }^{2}$ Departemen Teknik Sipil dan Lingkungan, Universitas Gadjah Mada, Yogyakarta \\ Email: saputra@ugm.ac.id
}

\begin{abstract}
The construction of a nonlevel railway crossing in Pucung Lor Kroya was aimed to improve safety and smooth traffic between railways and roads. Increasing frequency of railways through the Double Track Railway Project of South Java demands a fast pace construction of railway crossing without disrupting any railway traffic. So, the overpass structure will be built using Corrugated Mortar Busa Pusjatan (CMP) technology with Corrugated Steel Plate (CSP) on a curve structure 1 (P1) with a 25-meter span and curve structure 2 (P2) with a 12-meters span. When construction began, planners added reinforced concrete layers until composite with CSP to increase structural capacity and became structural protectors if CSP yielded or corrosions. Overpass modeling was done using MIDAS Civil 2019 based on finite element 3D to check strength capacity and service limits. The addition of reinforced concrete structures to composites with CSP is also compared to the non-composite design of CMP Pusjatan to see the effect on internal forces, stress, and deflection of CSP although the stress on foam mortar. Based on the results, the composite design overpass analysis satisfies compression-bending and shearing capacity checks based on Ultimate Limit States (ULS-PBKT) and service limit based on Serviceability Limit State (SLS-PBL). The addition of reinforced concrete to composite with CSP increases safety factor value because CSP stresses are lower than non-composite designs. The potential collapses from foam mortar can also be reduced as the structure becomes rigid.
\end{abstract}

Keywords: overpass, composite, corrugated steel, foam mortar

\section{PENDAHULUAN}

Indonesia merupakan salah satu negara di kawasan Asia Tenggara yang mengalami perkembangan infrastruktur secara masif. Sejak 2014 lalu, sektor infrastruktur menjadi fokus pemerintah untuk mendorong pertumbuhan ekonomi negara melalui program Proyek Strategis Nasional (PSN).

Pembangunan jalan rel double track di lintas selatan melalui Proyek Double Track Jawa Selatan akan meningkatkan frekuensi perjalanan kereta api dan mempersingkat waktu perjalanan. Salah satu daerah yang dilintasi oleh jalan rel ini adalah Kecamatan Kroya, Kabupaten Cilacap, Provinsi Jawa Tengah. Sebagai upaya untuk meningkatkan keselamatan dan kelancaran perjalanan kereta api beserta lalu lintas jalan, Direktorat Jenderal Perkeretaapian Kementerian Perhubungan telah membangun perlintasan tidak sebidang di JPL 482 Desa Pucung Lor, Kecamatan Kroya, Kabupaten Cilacap. Hal ini sesuai dengan Undang-Undang Nomor 23 Tahun 2016 tentang Perkeretaapian pasal 94 yang satu berbunyi "Untuk keselamatan perjalanan kereta api dan pemakai jalan, perlintasan sebidang yang tidak mempunyai izin harus ditutup".

Proses perencanaan perlintasan tidak sebidang di JPL 482 awalnya direncanakan menggunakan underpass, namun struktur perlintasan yang terealisasi akhirnya dipilih 
menggunakan overpass karena muka air tanah yang dangkal di sekitar lokasi. Struktur overpass yang direncanakan tidak menggunakan girder beton bertulang dikarenakan keterbatasan anggaran yang sudah ditetapkan. Selain itu, proses konstruksi yang dituntut cepat selesai tanpa mengganggu perjalanan kereta api di bawahnya turut menjadi tantangan bagi perencana dalam hal pemilihan struktur yang akan digunakan. Setelah melalui berbagai pertimbangan, akhirnya dipilih struktur overpass dengan 3 bentang dan 2 tipe pelengkung seperti pada Gambar 1 . Pelengkung tipe 1 (P1) dan tipe 2 (P2) direncanakan menggunakan baja bergelombang atau Corrugated Steel Plate (CSP) yang ditimbun dengan material ringan mortar busa di atasnya. Teknologi tersebut dikembangkan oleh Direktorat Bina Teknik Jalan dan Jembatan (Pusjatan) Kementerian PUPR dengan nama Corrugated Steel Mortar Busa Pusjatan (CMP).

Pusjatan (2016) menyatakan bahwa Teknologi CMP mendukung proses konstruksi untuk mempercepat pelaksanaan hingga 50\% tanpa mengabaikan keselamatan dan keamanan lalu lintas di bawahnya dengan biaya yang jauh lebih murah hingga $70 \%$ dibandingkan overpass konvensional (girder beton bertulang). Hal tersebut dimungkinkan karena struktur baja bergelombang turut menjadi bekisting timbunan di atasnya. Pemilihan material timbunan ringan mortar busa yang hanya memiliki berat $6 \mathrm{kN} / \mathrm{m}^{3}$ hingga $8 \mathrm{kN} / \mathrm{m}^{3}$ mampu meminimalkan konsolidasi tanah di bawahnya. Tanah akan mengalami penurunan atau konsolidasi jika terdapat beban signifikan yang bekerja di atasnya. Mortar busa bersifat ringan sehingga mengurangi risiko penurunan tanah.

Seiring berjalannya pembangunan, perencana meminta menambahkan struktur beton bertulang sebagai lining baja bergelombang pada pelengkung agar menjadi komposit. Perubahan ini bertujuan untuk menambah kapasitas daya dukung struktur serta melindungi struktur timbunan mortar busa jika baja bergelombang rusak akibat korosi maupun leleh akibat temperatur tinggi karena terbakar. Sedangkan pada desain aslinya, teknologi CMP Pusjatan tidak menggunakan lapisan beton bertulang pada struktur CSP.

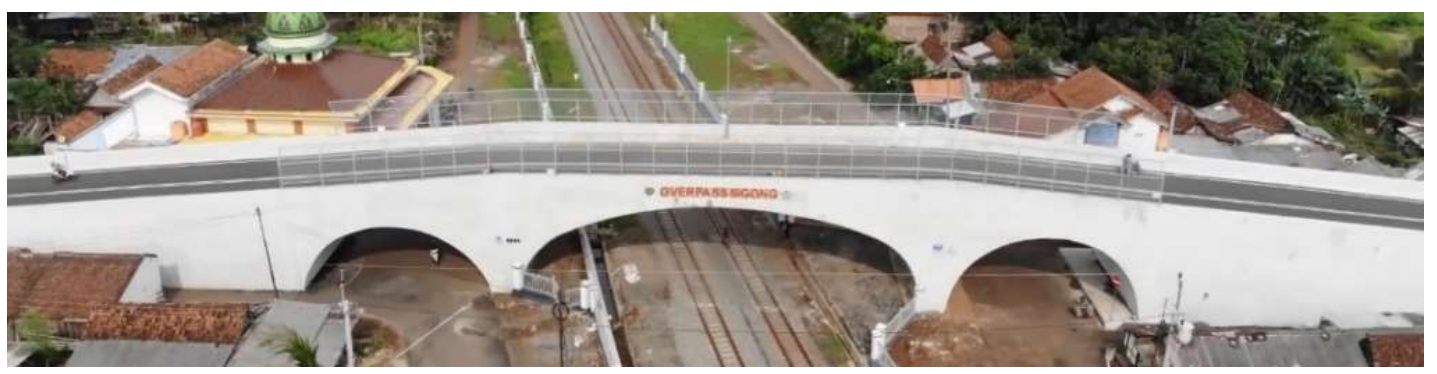

(a)

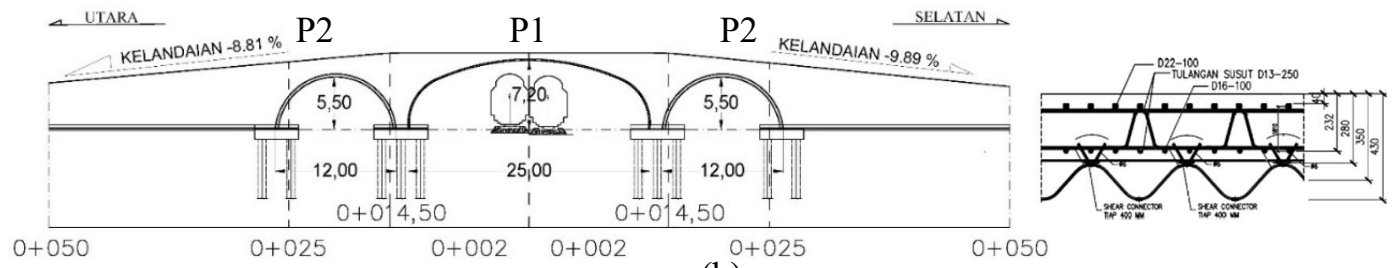

(b)

Gambar 1. Overpass JPL 482 Desa Pucung Lor, Kecamatan Kroya, Kabupaten Cilacap:

(a) Foto udara, (b) Gambar desain perencanaan. (Satker PLS2 Jateng, 2019) 
Dengan latar belakang tersebut, dilakukan studi analisis struktur atas overpass di JPL 482 Desa Pucung Lor, Kecamatan Kroya, Kabupaten Cilacap menggunakan software MIDAS Civil 2019 dengan pembebanan yang mengacu pada SNI 1725:2016. Penelitian ini membahas tentang pengaruh penambahan beton bertulang sebagai struktur komposit dengan CSP terhadap performa overpass secara keseluruhan dan studi komparasi untuk melihat interaksi terhadap struktur jika overpass dibangun menggunakan desain CMP Pusjatan, yaitu tanpa menggunakan beton bertulang pada struktur CSP (non komposit). Dampak penambahan biaya dari penambahan beton bertulang tidak dikaji.

\section{METODOLOGI PENELITIAN}

Struktur overpass Pucung Lor Kroya dibangun menggunakan CSP mutu SS400 dengan $f_{y}=245 \mathrm{MPa}$ dan lapisan beton bertulang mutu $30 \mathrm{MPa}$. Secara garis besar, pemodelan struktur overpass baik desain komposit maupun non komposit dilakukan menggunakan software MIDAS Civil 2019 dengan pembebanan jembatan mengacu pada SNI 1725:2016 tentang Pembebanan untuk Jembatan dan SNI 2833:2016 tentang Perencanaan Jembatan terhadap Beban Gempa.

Beban yang digunakan pada pemodelan meliputi berat sendiri (MS), beban mati tambahan (MA), beban kendaraan truk "T" (TT), beban angin struktur (EWS), beban angin kendaraan (EWL), beban akibat temperatur seragam (EUn), dan beban gempa (EQ) dengan data respons spektrum yang diperoleh dari Aplikasi Lini Beta Pusjatan (petagempa.pusjatan.pu.go.id).

Analisis kapasitas dan batas layan struktur komposit ditinjau berdasarkan RSNI T-122004 tentang Perencanaan Struktur Beton untuk Jembatan dan RSNI T-03-2005 tentang Perencanaan Struktur Baja untuk Jembatan menggunakan Perancangan Beban Kekuatan Terfaktor (PBKT) dan Perancangan Batas Layan (PBL). Sementara analisis dan kontrol tegangan pada CSP ditinjau berdasarkan Corrugated Steel Pipe Institue (CSPI) Handbook of Steel Drainage \& Highway Construction (2007) menggunakan analisis compression failure.

Tipikal penampang baja bergelombang (CSP) terdiri dari ukuran pitch, depth, dan tebal penampang seperti yang ditunjukkan pada Gambar 2.

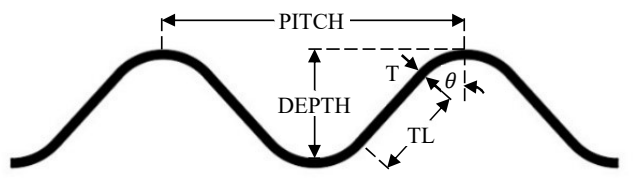

Gambar 2. Tipikal penampang CSP

\section{Pemodelan Overpass pada MIDAS Civil 2019}

Pada struktur komposit desain perencanaan, P1 dan P2 dimodelkan sebagai line element. Sedangkan mortar busa dimodelkan sebagai 3D solid element dengan bentuk mesh triangular prism. Setelah dilakukan trial secara otomatis oleh software, didapat ukuran mesh efektif sebesar $1000 \mathrm{~mm}$. Bentuk keseluruhan overpass menjadi seperti pada Gambar 3.

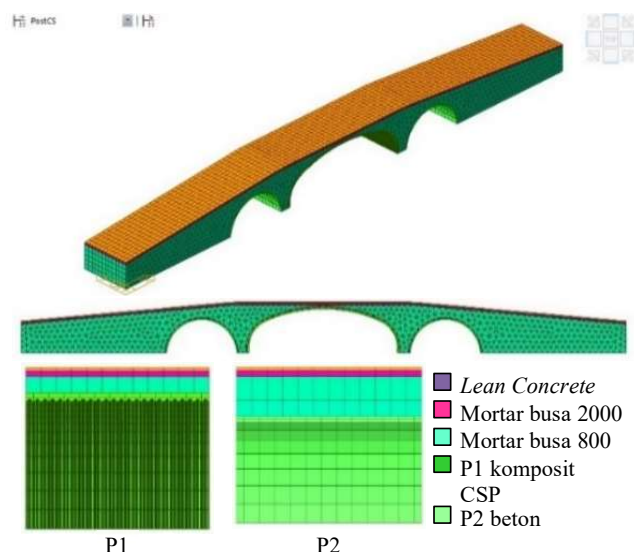

Gambar 3. Pemodelan overpass struktur komposit CSP beton bertulang

Sementara pada desain CMP Pusjatan non komposit, pemodelan hanya dibedakan pada jenis penampang yang berupa CSP saja tanpa beton bertulang seperti pada Gambar 4 . 

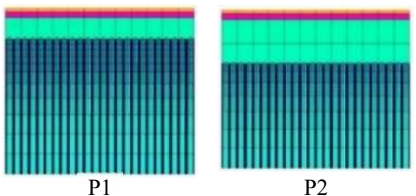

$\square$ Lean Concrete

$\square$ Mortar busa 2000

$\square$ Mortar busa $800 \mathrm{kPa}$

1 Baja

bergelombang

(CSP)

Gambar 4. Pemodelan overpass struktur non komposit CMP Pujatan

\section{Perancangan Beban dan Kekuatan Terfaktor (PBKT)}

Perhitungan analisis kapasitas tekan-lentur dan kontrol geser mengikuti standar acuan RSNI T-12-2004 tentang Perencanaan Struktur Beton untuk Jembatan seperti pada Gambar 5. Analisis kapasitas tekan-lentur menghasilkan diagram interaksi tekan-lentur.

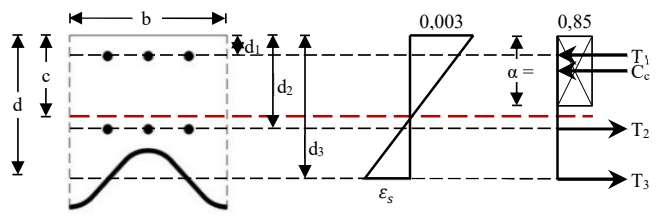

Gambar 5. Perhitungan kapasitas tekanlentur struktur komposit

Untuk analisis geser, digunakan kapasitas geser penampang komposit yaitu gabungan kapasitas geser beton bertulang $\left(V_{c}\right)$ dan kapasitas geser CSP $\left(V_{S}\right)$. Gaya geser yang terjadi tidak melebihi kuat geser tereduksi.

\section{Perancangan Batas Layan (PBL)}

RSNI T-12-2004 tentang Perencanaan Struktur Beton untuk Jembatan membatasi tegangan izin beton tidak boleh melampaui $0,45 f_{c}{ }^{\prime}$. Selanjutnya, lendutan yang diizinkan akibat beban rencana untuk daya layan tidak melebihi $\mathrm{L} / 250$ dan untuk beban hidup layan tidak melebihi L/800.

\section{Analisis Compression Failure CSP}

Perhitungan analisis kapasitas profil baja bergelombang dengan tipe struktur yang ditimbun (burried structure) menurut Canadian Highway Bridges Design Code (CHBDC, 2007) dikontrol menggunakan parameter utama, yaitu compression failure. Nilai dari compression failure harus dihitung pada kondisi ultimit yaitu tegangan yang terjadi pada struktur $\left(\sigma_{u}\right)$ tidak boleh melebihi kekuatan dari struktur baja bergelombang yang telah terfaktor $\left(f_{b}\right)$ seperti pada Persamaan (1).

$\sigma \leq f_{b}(\mathrm{MPa})$

Perhitugan nilai compression failure $\left(f_{b}\right)$ dapat menggunakan Persamaan (2) dan Persamaan (3).

untuk $R \leq R e$,

$f_{b}=\phi_{t} f_{m}\left[f_{y}-\frac{\left(f_{y} K R\right)^{2}}{12 E r^{2} \rho}\right]$

untuk $R>R e$,

$f_{b}=\frac{3 \phi_{t} \rho f_{m} E}{\left[\frac{K R}{r}\right]^{2}}$

dengan,

$\phi_{t}=$ faktor tahanan $=0,8$

$f_{m}=1,0$ untuk struktur tunggal, dan $\left(0,85+\frac{0,3 S}{D_{h}}\right) \leq 1,00$ untuk struktur non tunggal

$S=$ jarak antar struktur CSP (m)

$D_{h}=$ bentang struktur terpanjang $(\mathrm{m})$

$E=$ modulus elastisitas CSP (MPa)

$R=$ radius baja bergelombang $(\mathrm{mm})$

$R e=$ radius ekuivalen $(\mathrm{mm})$

$R \mathrm{e}=\frac{r}{K}\left(\frac{6 E \rho}{f_{y}}\right)^{1 / 2}$

$r=$ jari-jari girasi profil CSP (mm)

$f_{y}=$ tegangan leleh CSP $(\mathrm{MPa})$

$\rho=\left(1000 \cdot \frac{H+H \prime}{R}\right)^{1 / 2}$

$H=$ tinggi timbunan $(\mathrm{m})$

$H^{\prime}=1 / 2$ dari tinggi struktur $(\mathrm{m})$

$K=$ faktor kekakuan $=\lambda\left(\frac{E I}{E_{m} R^{3}}\right)^{0,25}$

$I=$ momen inersia penampang $\left(\mathrm{mm}^{4}\right)$

$E_{m}=$ modulus elastisitas timbunan (MPa)

$\lambda=1,22\left[1+1,6\left(\frac{E I}{E_{m} R^{3}}\right)^{0,25}\right]$

\section{HASIL DAN PEMBAHASAN}

Hasil Analisis Overpass pada MIDAS Civil

Dari hasil analisis pemodelan overpass desain perencanaan (komposit CSP beton 
bertulang) menggunakan MIDAS Civil 2019, diperoleh kombinasi pembebanan Kuat I (ultimate) dan Layan I (service) yang memiliki pengaruh paling besar terhadap struktur overpass. Rekapitulasi reaksi tumpuan, gaya-gaya dalam, tegangan, dan lendutan maksimum pada P1 dan P2 ditunjukkan oleh Tabel 1.

\section{Analisis Kapasitas dan Batas Layan berdasarkan PBKT dan PBL}

Hasil analisis kapasitas tekan-lentur (Pn-Mn) struktur komposit P1 dan P2 desain perencanaan ditunjukkan pada grafik diagram interaksi tekan lentur yang dapat dilihat pada Gambar 6 dan Gambar 7.

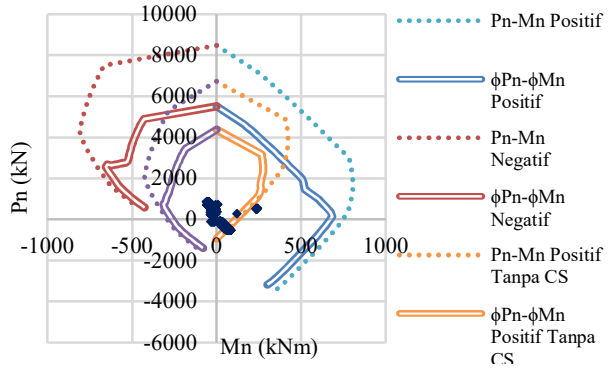

Gambar 6. Diagram interaksi tekan-lentur P1

Berdasarkan diagram interaksi pada Gambar 6, terlihat bahwa kapasitas struktur komposit P1 masih dapat mengampu gaya dalam aksial dan lentur dari setiap elemen pada P1 akibat kombinasi pembebanan Kuat I. Titik-titik gaya yang terjadi masih jauh di dari batas kurva kapasitas struktur komposit tereduksi. Sehingga pada kondisi struktur komposit masih utuh, struktur P1 sangat aman.

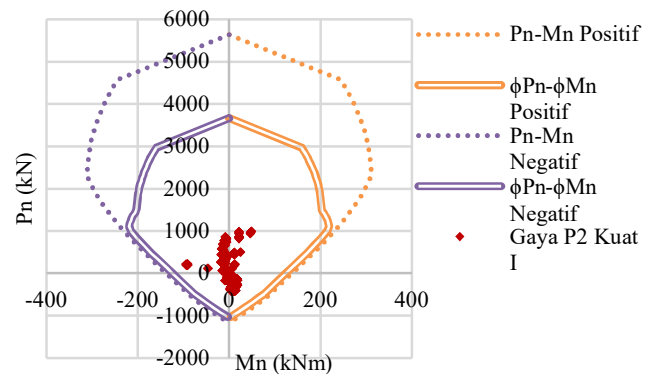

Gambar 7. Diagram interaksi tekan-lentur P2

Berbeda halnya pada saat kondisi CSP sudah leleh dan tidak menjadi bagian dari struktur, sebagian titik-titik gaya aksial dan lentur P1 sudah melebihi kurva kapasitas struktur tanpa CSP tereduksi. Apabila titik gaya melebihi kurva kapasitas maka struktur dapat berpotensi mengalami kegagalan. Sementara pada P2, kapasitas struktur beton bertulang P2 masih dapat mengampu gaya dalam dari setiap elemen P2 akibat kombinasi pembebanan Kuat I. Titik-titik gaya aksial dan lentur pada P2 masih jauh di dari batas kurva kapasitas struktur tereduksi seperti yang terlihat pada Gambar 7. Sehingga dapat dikatakan struktur P2 sangat aman.

Tabel 1. Rekapitulasi hasil analisis overpass struktur komposit.

\begin{tabular}{|c|l|c|c|c|c|}
\hline \multirow{3}{*}{ Struktur } & \multicolumn{1}{|c|}{ Hasil analisis } & \multirow{2}{*}{$\begin{array}{c}\text { Kombinasi } \\
\text { pembebanan }\end{array}$} & \multicolumn{2}{|c|}{ Nilai } & \multirow{2}{*}{ Satuan } \\
\cline { 4 - 6 } & & Maks. & Min. & \\
\hline \multirow{5}{*}{ P1 } & Reaksi tumpuan $(R)$ & Layan I & 409,67 & 204,02 & $\mathrm{kN}$ \\
& Gaya Aksial $(F x)$ & Kuat I & 540,23 & $-866,63$ & $\mathrm{kN}$ \\
& Momen lentur $(M y)$ & Kuat I & 242,90 & $-60,35$ & $\mathrm{kNm}$ \\
& Gaya geser $(V z)$ & Kuat I & 252,29 & $-245,69$ & $\mathrm{kN}$ \\
& Tegangan beton $\left(\sigma_{C}\right)$ & Layan I & 1,29 & $-8,84$ & $\mathrm{MPa}$ \\
& Lendutan $(\delta)$ & Layan I & 0,09 & $-6,25$ & $\mathrm{~mm}$ \\
\hline \multirow{3}{*}{ P2 } & Reaksi tumpuan $(R)$ & Layan I & 875,39 & 146,53 & $\mathrm{kN}$ \\
& Gaya Aksial $(F x)$ & Kuat I & 424,27 & $-992,54$ & $\mathrm{kN}$ \\
& Momen lentur $(M y)$ & Kuat I & 48,68 & $-94,28$ & $\mathrm{kNm}$ \\
& Gaya geser $(V z)$ & Kuat I & 107,63 & $-104,81$ & $\mathrm{kN}$ \\
& Tegangan beton $\left(\sigma_{C}\right)$ & Layan I & 5,97 & $-7,82$ & $\mathrm{MPa}$ \\
& Lendutan $(\delta)$ & Layan I & 0,59 & $-0,74$ & $\mathrm{~mm}$ \\
\hline \hline
\end{tabular}


Analisis geser pada struktur P1 dihitung sebagai berikut.

Beton,

$$
\begin{aligned}
\frac{V_{u} d}{M_{u}} & =\frac{252,29 \times 0,35}{242,9}=0,364<1, \text { maka: } \\
V_{c} & =\left(\sqrt{f_{c}^{\prime}}+120 \rho_{w} \frac{V_{u} d}{M_{u}}\right) \frac{b d}{7} \\
& =(\sqrt{30}+120(0,015 \times 0,364)) \frac{776 \times 350}{7} \\
V_{c} \quad & =237,87 \mathrm{kN}<0,3 \sqrt{f_{c}^{\prime}} b d=446,28 \mathrm{kN}
\end{aligned}
$$

Baja tulangan dan CSP,

$$
\begin{array}{ll}
V_{s} & =0,6 \times f_{y} \times A_{s} \\
V_{s 1} & =0,6 \times 390 \times 2660,93=622,66 \mathrm{kN} \\
V_{s 2} & =0,6 \times 390 \times 1407,43=329,34 \mathrm{kN} \\
V_{s 3} & =0,6 \times 245 \times 8928=1312,42 \mathrm{kN}
\end{array}
$$

Kapasitas geser total,

$$
\begin{aligned}
\phi V_{n}= & \phi\left(V_{c}+V_{s 1}+V_{s 2}+V_{s 3}\right) \\
= & 0,7(237,87+622,66+329,34+ \\
& 1312,42) \\
\phi V_{n}= & 1751,60 \mathrm{kN}>V_{u}=252,29 \mathrm{kN}
\end{aligned}
$$

Dengan perhitungan yang sama, kapasitas geser pada P2 masih masih mampu menahan gaya geser yang terjadi. Struktur P1 dan P2 aman terhadap gaya geser.

Pada analisis batas layan berdasarkan PBL, tegangan dan lendutan izin struktur komposit P1 dihitung sebagai berikut.

$$
\begin{aligned}
\sigma_{\text {izin }} & =0,45 \times f_{c}{ }^{\prime} \quad=0,45 \times 30 \\
\sigma_{\text {izin }} & =13,50 \mathrm{MPa}>\sigma_{u}=8,84 \mathrm{MPa}(\mathrm{OK}) \\
\delta_{\text {izin }} & =\mathrm{L} / 800=25,0125 \times 1000 / 800 \\
\delta_{\text {izin }} & =31,27 \mathrm{~mm}>\delta=6,25 \mathrm{~mm}(\mathrm{OK})
\end{aligned}
$$

Sedangkan pada P2, analisis batas layan dihitung sebagai berikut

$$
\begin{aligned}
\sigma_{\text {izin }} & =0,45 \times f_{c}{ }^{\prime} \quad=0,45 \times 30 \\
\sigma_{\text {izin }} & =13,50 \mathrm{MPa}>\sigma_{u}=8,84 \mathrm{MPa}(\mathrm{OK}) \\
\sigma_{\text {izin }} & =13,50 \mathrm{MPa}>\sigma_{u}=7,82 \mathrm{MPa}(\mathrm{OK}) \\
\delta_{\text {izin }} & =15,00 \mathrm{~mm}>\delta=0,74 \mathrm{~mm}(\mathrm{OK})
\end{aligned}
$$

Hasil analisis desain komposit P1 P2 berdasarkan PBKT dan PBL sama-sama memenuhi syarat kapasitas tekan-lentur, kapasitas geser, tegangan izin dan lendutan izin. Penambahan struktur beton bertulang menjadi komposit pada CSP masih memenuhi persyaratan perancangan. Tegangan tarik beton dapat diabaikan sesuai dengan RSNI-T-12-2004.

\section{Perbandingan Struktur Komposit dan Struktur Non Komposit}

Pada desain perencanaan, struktur komposit dimodelkan dengan 2 tahap Construction Stage Analysis yaitu initial condition dan service condition. Shear connector tipe "V" diameter $6 \mathrm{~mm}$ dengan jarak setiap $40 \mathrm{~cm}$ seperti pada Gambar 1 juga dimodelkan pada MIDAS Civil agar menjadi struktur komposit seutuhnya. Hasil pemodelan struktur komposit CSP beton bertulang P1 dan struktur beton bertulang P2 pada desain perencanaan overpass kemudian dibandingkan dengan desain non komposit CMP Pusjatan untuk melihat perbedaan gaya dalam, tegangan, dan lendutan pada CSP serta pengaruh terhadap mortar busa dari modifikasi struktur yang dilakukan. Perbandingan gaya aksial dan momen CSP akibat kombinasi pembebanan Kuat I pada desain perencanaan dan desain CMP Pusjatan tersaji pada Tabel 2 dan Gambar 8.

Penambahan lapisan beton bertulang menjadi struktur komposit pada P1 menyebabkan gaya aksial dan momen pada CSP lebih kecil sebesar 46,36\% jika dibandingkan hanya menggunakan CSP saja. Gaya dalam yang lebih kecil dapat menghemat dimensi yang diperlukan dari fondasi, sehingga biaya semakin ekonomis. Keuntungan lainnya adalah struktur atas overpass dapat lebih aman ketika CSP leleh akibat temperatur yang tinggi karena kebakaran di bawah struktur ataupun korosi karena faktor alam. Lapisan beton bertulang di atas CSP berfungsi sebagai pelindung sekaligus pengaman jika sewaktu-waktu CSP mengalami kegagalan struktur. 
Tabel 2. Perbandingan gaya dalam CSP Kuat I desain komposit dan CMP Pusjatan.

\begin{tabular}{|c|l|l|c|c|c|c|c|}
\hline Struktur & \multicolumn{1}{|c|}{ Desain } & \multicolumn{1}{|c|}{ Tipe } & $\begin{array}{c}\mathrm{Fx}+ \\
(\mathrm{kN})\end{array}$ & $\begin{array}{c}\mathrm{Fx}- \\
(\mathrm{kN})\end{array}$ & $\begin{array}{c}\mathrm{My}+ \\
(\mathrm{kNm})\end{array}$ & $\begin{array}{c}\text { My- } \\
(\mathrm{kNm})\end{array}$ & $\begin{array}{c}\text { Margin } \\
\text { rata-rata }\end{array}$ \\
\hline $\mathrm{P} 1$ & Perencanaan & $\begin{array}{l}\text { Komposit } \\
\text { CSP+Beton }\end{array}$ & 376,7 & $-291,8$ & 7,72 & $-1,92$ & $-46,36 \%$ \\
\hline $\mathrm{P} 2$ & CMP Pusjatan & $\begin{array}{l}\text { Corrugated } \\
\text { Steel Plate }\end{array}$ & 511,39 & $-528,6$ & 15,9 & $-5,17$ & - \\
\hline
\end{tabular}

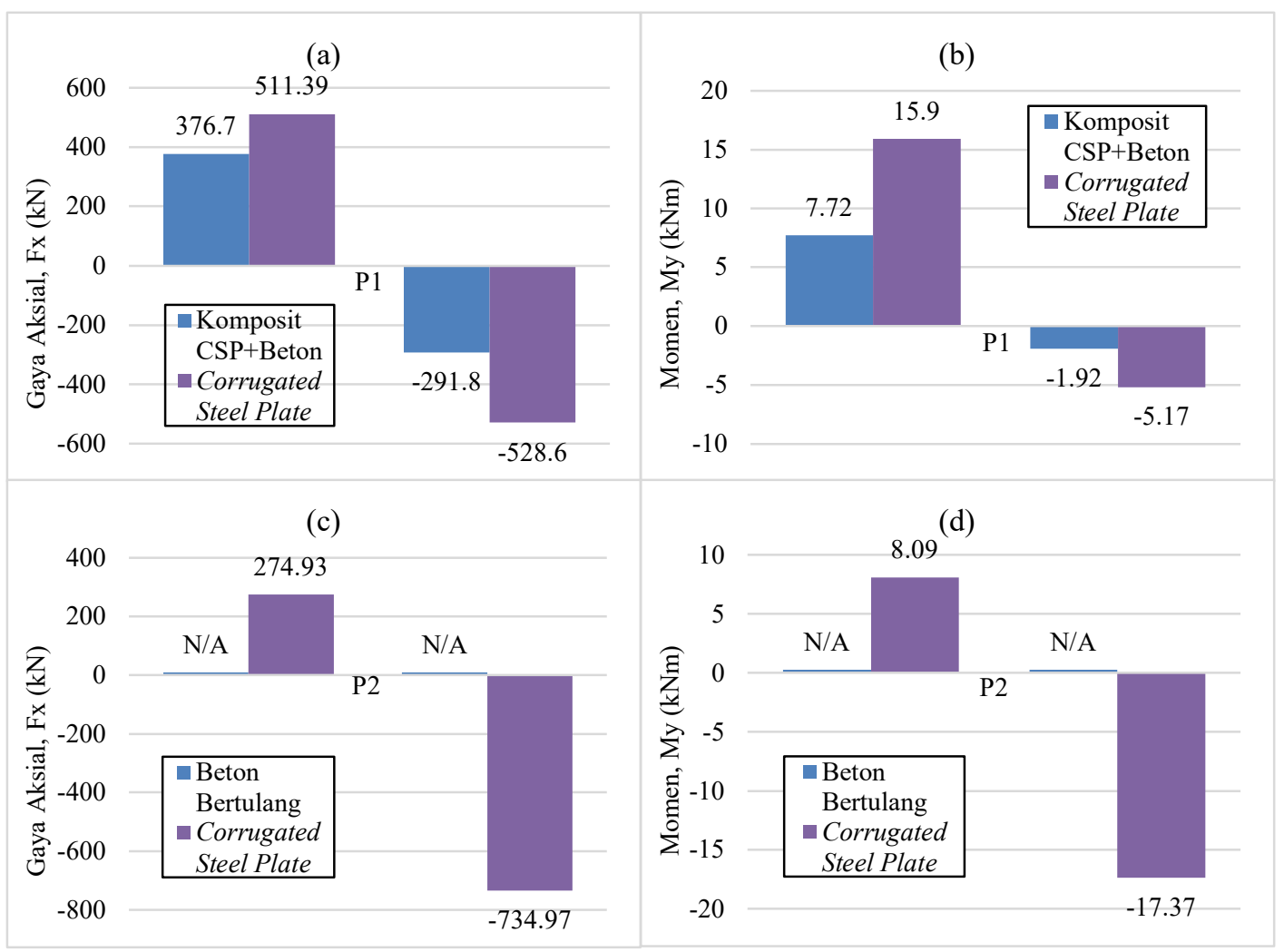

Gambar 8. Grafik perbandingan gaya aksial dan momen CSP Kuat I desain perencanaan dan CMP Pusjatan: (a) Aksial P1, (b) Momen P1, (c) Aksial P2, (d) Momen P2.

Untuk gaya geser P1 dan P2, masing-masing desain perencanaan maupun desain CMP Pusjatan memiliki kapasitas geser memadai untuk mengampu gaya geser yang terjadi. Hasil kontrol gaya geser pada P1 P2 disajikan pada Tabel 3.

Gaya geser yang terjadi pada CSP desain CMP Pusjatan jauh lebih kecil karena sebagian besar gaya geser ditransfer pada struktur mortar busa di atasnya. Hal ini membuat nilai faktor aman (SF) jauh lebih tinggi dibanding struktur komposit maupun beton bertulang pada desain perencanaan.

Tegangan dan lendutan yang terjadi pada CSP perlu dianalisis untuk mengetahui kapasitas compression failure dan deformation dari struktur CSP yang digunakan berdasarkan panduan CSPI yang 
berbasis CHBDC 2007. Tegangan ultimit tidak boleh melebihi kapasitas tegangan atau tegangan izin $\left(f_{b}\right)$ dari struktur sesuai dengan Persamaan (1). Hasil analisis tegangan ultimit pada P1 P2 desain komposit dan non komposit tersaji pada Tabel 4.

Tegangan CSP P1 pada desain CMP Pusjatan lebih besar dibandingkan dengan desain perencanaan. Sementara itu pada P2, desain perencanaan tidak terdapat tegangan CSP karena hanya menggunakan beton bertulang. Hal ini menyebabkan struktur P1 desain CMP Pusjatan memiliki nilai SF lebih kecil dibanding desain perencanaan yang menggunakan komposit beton bertulang. Penambahan struktur beton bertulang menjadi komposit dengan CSP pada P1 membuat struktur CSP lebih aman karena tegangan ultimit yang dihasilkan lebih kecil.

Kontrol lendutan izin sama dengan evaluasi berdasarkan PBL, yaitu lendutan kurang dari L/800. Perbandingan lendutan P1 P2 desain perencanaan dan desain CMP Pusjatan tersaji pada Tabel 5 .

Lendutan yang terjadi pada P1 P2 desain CMP Pusjatan lebih besar dibanding desain perencanaan. Perbedaan lendutan tersebut disebabkan karena pada desain perencanaan struktur menjadi lebih kaku dengan adanya penambahan beton bertulang sehingga deformasi struktur menjadi lebih kecil sehingga menyebabkan nilai faktor aman meningkat dari lendutan yang diizinkan.

Tabel 3. Kontrol gaya geser Kuat I desain perencanaan dan desain CMP Pusjatan.

\begin{tabular}{|c|l|l|c|c|c|c|c|}
\hline Struktur & \multicolumn{1}{|c|}{ Desain } & \multicolumn{1}{c|}{ Tipe } & $\mathrm{Vu}+(\mathrm{kN})$ & $\mathrm{Vu}-(\mathrm{kN})$ & $\phi \mathrm{Vn}(\mathrm{kN})$ & $\phi \mathrm{Vn}>\mathrm{Vu}$ & $S F$ \\
\hline P1 & Perencanaan & $\begin{array}{l}\text { Komposit } \\
\text { CSP+Beton } \\
\text { Corrugated } \\
\text { Steel Plate }\end{array}$ & 252,29 & $-245,69$ & 1583,33 & OK! & 6,28 \\
\hline P2 & Perencanaan & $\begin{array}{l}\text { Beton } \\
\text { Bertulang } \\
\text { Corrugated } \\
\text { Steel Plate }\end{array}$ & 107,63 & $-104,81$ & 611,30 & OK! & 5,68 \\
\hline
\end{tabular}

Tabel 4. Perbandingan tegangan ultimit CSP Kuat I desain komposit dan non komposit.

\begin{tabular}{|c|l|c|c|c|c|c|}
\hline Struktur & \multicolumn{1}{|c|}{ Tipe } & $\begin{array}{c}\sigma_{\mathrm{u}} \max \\
(\mathrm{MPa})\end{array}$ & $\begin{array}{c}\sigma_{\mathrm{u}} \min \\
(\mathrm{MPa})\end{array}$ & $\begin{array}{c}f_{b} \\
(\mathrm{MPa})\end{array}$ & $\sigma_{\mathrm{u}} \leq f_{b}$ & $S F$ \\
\hline \multirow{2}{*}{$\mathrm{P} 1$} & Komposit CSP+Beton & 70,79 & $-40,46$ & 169,59 & OK! & 2,40 \\
& Corrugated Steel Plate & 90,89 & $-69,35$ & 169,59 & OK! & 1,87 \\
\hline \multirow{2}{*}{$\mathrm{P} 2$} & Beton Bertulang & N/A & N/A & N/A & N/A & N/A \\
& Corrugated Steel Plate & 36,81 & $-99,33$ & 172,82 & OK! & 1,74 \\
\hline
\end{tabular}

Tabel 5. Perbandingan lendutan CSP Layan I desain perencanaan dan desain CMP Pusjatan.

\begin{tabular}{|c|c|c|c|c|c|}
\hline Struktur & Tipe & $\delta \max (\mathrm{mm})$ & $\delta$ izin $(\mathrm{mm})$ & $\delta \max \leq \delta$ izin & $S F$ \\
\hline $\mathrm{P} 1$ & \begin{tabular}{|l} 
Komposit \\
CSP+Beton \\
Corrugated \\
Steel Plate
\end{tabular} & $\begin{array}{l}6,25 \\
8,88\end{array}$ & 31,27 & $\begin{array}{l}\mathrm{OK} ! \\
\mathrm{OK} !\end{array}$ & $\begin{array}{l}5,00 \\
3,52\end{array}$ \\
\hline $\mathrm{P} 2$ & $\begin{array}{l}\text { Beton Bertulang } \\
\text { Corrugated } \\
\text { Steel Plate }\end{array}$ & $\begin{array}{l}0,74 \\
0,95\end{array}$ & 15,00 & $\begin{array}{l}\text { OK! } \\
\text { OK! }\end{array}$ & $\begin{array}{l}20,27 \\
15,79\end{array}$ \\
\hline
\end{tabular}


Pengaruh modifikasi struktur P1 P2 desain perencanaan juga dianalisis terhadap struktur mortar busa di atasnya. Titik tinjau tegangan diamati pada tengah bentang P1 sisi bagian luar pada lapis timbunan mortar busa $800 \mathrm{kPa}$ dan mortar busa $2000 \mathrm{kPa}$ karena memiliki resultan tegangan efektif (Von-Mises) paling besar. Akan tetapi, tegangan dianalisis menggunakan teori Mohr-Coulumb karena mortar busa termasuk material yang getas (brittle material).

Pada analisis ini, kuat tarik mortar busa didekati dengan koefisien konversi kuat tarik terhadap kuat tekan dikarenakan data yang diperoleh hanya berdasarkan pengujian kuat tekan saja. Tegangan prinsipal $\left(\sigma_{1}, \sigma_{2}, \sigma_{3}\right)$ diplot pada grafik tegangan tarik dan tegangan dasar untuk memperoleh grafik lingkaran Mohr dengan diameter sebesar $\sigma_{3}$ $\sigma_{1}$. Selanjutnya, nilai tegangan ultimit mortar busa diplot pada grafik untuk memperoleh daerah kegagalan (failure) dari gradien yang dihasilkan antara grafik lingkaran Mohr tegangan ultimit tekan dan tarik. Diperoleh grafik lingkaran Mohr-Coulumb untuk mortar busa $800 \mathrm{kPa}$ dan mortar busa 2000 kPa seperti pada Gambar 9.

Grafik lingkaran Mohr mortar busa $800 \mathrm{kPa}$ pada desain CMP Pusjatan terlihat melebihi kurva garis failure dari tegangan ultimit yang ditandai dengan area arsiran berwarna merah. Sebaliknya, grafik lingkaran Mohr mortar busa desain perencanaan masih berada di area dalam kurva garis failure. Pada tinjauan mortar busa $2000 \mathrm{kPa}$, grafik lingkaran Mohr desain CMP Pusjatan dan desain perencanaan terlihat sudah melebihi kurva garis failure. Akan tetapi, terdapat perbedaan signifikan dari luasan area arsiran tersebut. Area arsiran merah pada grafik desain CMP Pusjatan memiliki luasan yang jauh lebih besar dibandingkan dengan area arsiran biru pada grafik desain perencanaan.

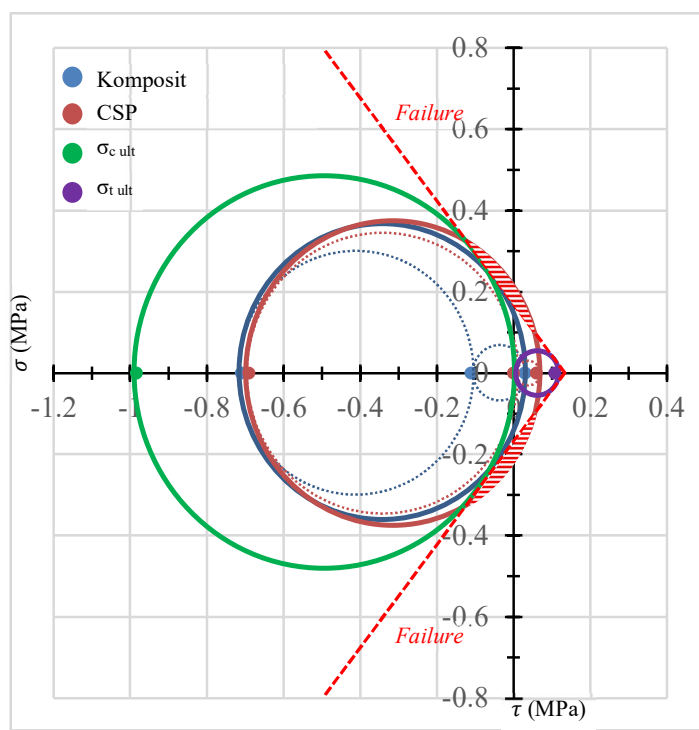

(a)

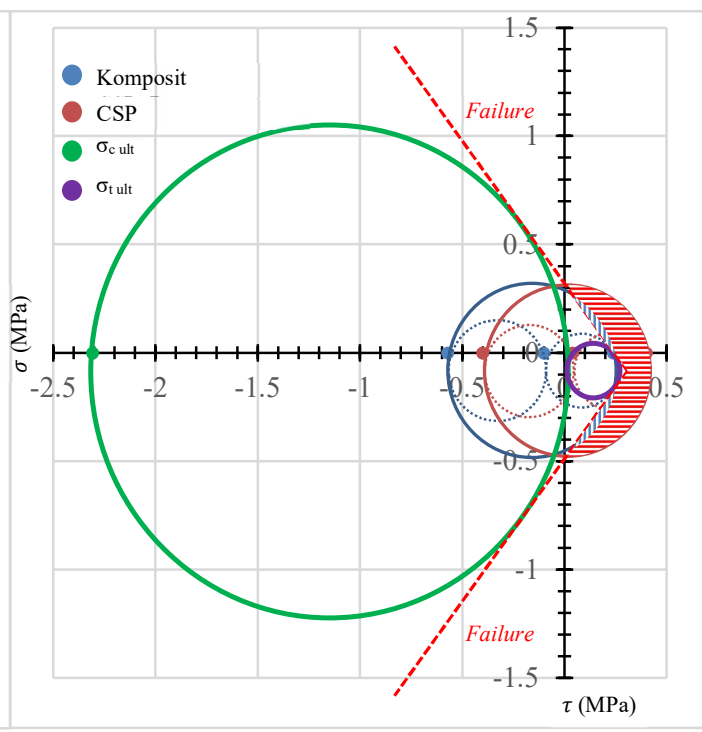

(b)

Gambar 9. Grafik lingkaran Mohr-Coulumb desain perencanaan dan CMP Pusjatan:

(a) Mortar Busa $800 \mathrm{kPa}$ dan (b) Mortar Busa $2000 \mathrm{kPa}$. 
Area yang berada di luar kurva garis failure menandakan struktur dapat berpotensi mengalami kegagalan akibat tegangan yang terjadi melebihi kapasitasnya (overstressed). Semakin besar luasan area grafik di luar kurva garis failure, maka potensi kegagalan struktur juga akan semakin besar. Dalam hal ini, mortar busa secara struktural akan meneruskan gaya-gaya yang bekerja pada lapis perkerasan sampai ke struktur P1 dan P2. Pada kasus material getas seperti mortar busa, struktur dapat retak, terdegradasi, bahkan runtuh. Nilai tegangan prinsipal yang besar pada desain CMP Pusjatan disebabkan karena mortar busa menyerap tegangan lebih besar untuk mengkompensasi nilai lendutan yang besar pada struktur CSP. Penambahan struktur beton bertulang menjadi komposit pada desain perencanaan menyebabkan struktur lebih kaku sehingga lendutan yang terjadi lebih kecil dan tegangan yang diserap oleh mortar busa dapat berkurang.

\section{KESIMPULAN}

Desain perencanaan struktur komposit Corrugated Steel Plate (CSP) beton bertulang Pelengkung 1 (P1) dengan bentang 25 meter dan struktur beton bertulang Pelengkung 2 (P2) dengan bentang 12 meter memenuhi persyaratan kapasitas dan batas layan berdasarkan Perancangan Beban Kekuatan Terfaktor (PBKT) dan Perancangan Batas Layan (PBL).

Struktur P1 komposit CSP beton bertulang desain perencanaan menghasilkan gaya aksial dan momen lebih kecil dibandingkan desain non komposit CMP Pusjatan dengan margin rata-rata $46,36 \%$. Nilai faktor aman desain perencanaan dengan struktur komposit CSP beton bertulang meningkat karena tegangan dan lendutan pada CSP lebih kecil dibandingkan desain non komposit CMP Pusjatan.

Grafik tegangan Mohr-Coulumb mortar busa $800 \mathrm{kPa}$ di tengah bentang P1 sisi luar desain non komposit CMP Pusjatan melebihi kurva garis failure untuk mengkompensasi nilai lendutan CSP yang besar. Pada mortar busa
$2000 \mathrm{kPa}$, grafik tegangan desain CMP Pusjatan melebihi kurva garis failure dengan area jauh lebih besar dibanding desain perencanaan komposit CSP beton bertulang. Penambahan struktur beton bertulang menjadi komposit dengan CSP dapat dijadikan alternatif desain karena struktur overpass secara keseluruhan lebih kaku dan aman sehingga menurunkan potensi keruntuhan mortar busa dan kegagalan CSP akibat leleh maupun korosi.

\section{DAFTAR PUSTAKA}

Bowles, J. E. (1996). "Foundation Analysis And Design", 5th edition. McGrawHill.

Badan Standarisasi Nasional. (2004). "RSNI T-12-2004 Perencanaan Struktur Beton Untuk Jembatan". Jakarta.

Badan Standarisasi Nasional. (2005). "RSNI T-03-2005 Perencanaan Struktur Baja Untuk Jembatan". Jakarta.

Badan Standarisasi Nasional. (2016). "SNI 1725:2016 Pembebanan untuk Jembatan". Jakarta.

Badan Standarisasi Nasional. (2016). SNI 2833:2016 Perencanaan Jembatan Terhadap Beban Gempa. Jakarta.

Canadian Standards Association. (2006). "CSA-S6-06 Canadian Highway and Bridge Design Code". Mississauga.

Corrugated Steel Pipe Institute. (2007). "Handbook of Steel Drainage and Highway Construction Products" (2nd ed.). Ontario.

Kementerian PUPR. (2015). "Surat Edaran Menteri PU No.41-46/SE/M/2015 tentang Pedoman Spesifikasi Material Ringan untuk Konstruksi Jalan". Jakarta.

Midasoft, inc. (2006). "Analysis for Civil Structures". Midasoft.

PLS2, S. (2019). "Youtube Pembangunan Overpass JPL 482 Pucung Lor Kroya". Dipetik Maret 15, 2021, dari 
P-ISSN 0853-8557, E-ISSN 2746-0185

https://www.youtube.com/watch?v= BOhQBmydG5U

Pusat Litbang Jalan dan Jembatan PUPR. (2016). "Teknologi Corrugated Mortar Busa Pusjatan (CMP)". Jakarta.

Pusat Litbang Jalan dan Jembatan PUPR. (2017). "Aplikasi Lini Beta Pusjatan". Dipetik Maret 15, 2021, dari

http://petagempa.pusjatan.pu.go.id/ 